\title{
The Association of Serum Ferritin and Metabolic Syndrome and Metabolic Syndrome Score in Korean Adults
}

\author{
Hyun Yoon ${ }^{1}$, Jae Seong $\mathrm{Go}^{2}$, Kang Uk Kim², Keon Woo Lee ${ }^{2}$ \\ ${ }^{1}$ Department of Biomedical Laboratory Science, Hanlyo University, Gwangyang 57764, Korea \\ ${ }^{2}$ Department of Radiological Science, Gwangyang Health College, Gwangyang 57764, Korea
}

\section{대한민국 성인에서 대사증후군 및 대사증후군 구성요소의 증가와 혈청 Ferritin의 관련성}

\author{
윤 현 $^{1}$, 고재성 ${ }^{2}$, 김광욱 $^{2}$, 이건우 $^{2}$ \\ ${ }^{1}$ 한려대학교 임상병리학과, ${ }^{2}$ 광양보건대학교 방사선과
}

\begin{abstract}
This study was conducted to assess the relationship amongst serum ferritin, and metabolic syndrome (MetS) and metabolic syndrome score (MSS) in Korean adults. The data of 16,096 adults (6,840 men as well as 4,916 premenopausal and 4,340 postmenopausal women) aged $\geq 20$ years in the Korean National Health and Nutrition Examination Survey (KNHANES) between 2010 and 2012 were analyzed. The prevalence rate of MetS was 3,978 (24.7\%) (men, 24.6\%; premenopausal women, $11.1 \%$; postmenopausal women, $40.3 \%$ ). The key study results were as follows: First, after the adjustment for relevant variables, the serum ferritin level $(\mathrm{M} \pm \mathrm{SE}$ ) was significantly higher ( $p$ $<0.001$ ) in the MetS group (men, $132.25 \pm 1.98 \mathrm{ng} / \mathrm{mL}$; premenopausal women, $39.89 \pm 1.49$ $\mathrm{ng} / \mathrm{mL}$; postmenopausal women, $73.45 \pm 1.14 \mathrm{ng} / \mathrm{mL}$ ) than in the non-MetS group (men, $111.08 \pm 1.01 \mathrm{ng} / \mathrm{mL}$; premenopausal women, $32.26 \pm 0.50 \mathrm{ng} / \mathrm{mL}$; postmenopausal women, $63.26 \pm 0.98 \mathrm{ng} / \mathrm{mL}$ ). Second, the serum ferritin levels increased as MSS increased in all groups (men, premenopausal women, and postmenopausal women) $(p<0.001)$. In conclusion, MetS and MSS increases were positively associated with higher serum ferritin levels.
\end{abstract}

Key words: Metabolic syndrome, Metabolic syndrome score, Serum ferritin

This is an Open Access article distributed under the terms of the Creative Commons Attribution Non-Commercial License (http://creativecommons.org/licenses/by-nc/4.0) which permits unrestricted non-commercial use, distribution, and reproduction in any medium, provided the original work is properly cited.

Copyright $\odot 2016$ The Korean Society for Clinical Laboratory Science. All rights reserved.
Corresponding author: Hyun Yoon Department of Biomedical Laboratory Science, Hanlyo University, 94-13 Hallyeodae-gil, Gwangyang-eup, Gwangyang 57764, Korea Tel: 82-61-760-1150

Fax: 82-61-761-6709 E-mail: yh9074@yahoo.co.kr

Received: October 14, 2016 Revised $1^{\text {st: }}$ November 4, 2016 Revised 2 ${ }^{\text {nd }}$ : November 6, 2016 Revised 3 ${ }^{\text {rd: }}$ November 12, 2016 Accepted: November 14, 2016

\section{Introduction}

Iron is a ubiquitous metal of vital importance to the normal physiologic processes of many organisms [1], and it is essential for many metabolic processes such as oxygen transport, DNA synthesis, and electron transport [2]. As a ferrous iron and ferric iron were active forms of iron, they was can catalyze generation of highly reactive oxygen species, such as hydroxyl, alkoxyl, and peroxyl radicals via Fenton and Haber-Weiss reactions [3]. The serum ferritin concentration reflects iron stores in the body because ferrous iron combines with apoferritin and is stored by ferritin in many organisms [4]. As an excessive accumulation of ferritin can increase the concentration of catalytically active free iron, and serum ferritin concentration has been considered a possible risk factor of various chronic diseases including cancer, car- 
diovascular disease, diabetes, and essential hypertension, in which oxidative stress is closely involved in pathogenesis [5-9].

A characteristic of metabolic syndrome (MetS) is insulin resistance, which the National Cholesterol Education Program Adult Treatment Panel III (NCEP-ATPIII) defined as exhibiting more than three out of the five risk factors for coronary artery disease, elevated blood pressure, elevated blood sugar, abdominal obesity, elevated triglycerides, and reduced high density lipoprotein cholesterol [10]. The five risk factors are directly related to an increased prevalence of cardio-cerebrovascular disease [11-13].

Recently, research on serum ferritin concentration and MetS has been conducted all over the world. However, the association of MetS and serum ferritin concentration is still being debated, as the findings vary across studies. That is, some report that MetS or its components are associated with serum ferritin concentration [14-17], others that they are not $[18,19]$. Some report that association of the MetS or serum ferritin levels differ according to sex [20,21]. The Republic of Korea is experiencing an increasing prevalence of diseases such as MetS and cardiovascular diseases. However, research on the association between MetS and serum ferritin concentration in Korean adults (men, premenopausal women, and postmenopausal women) is rare. Therefore, the present study sought to investigate the association between MetS and its components and serum ferritin concentration in Korean men, premenopausal women, and postmenopausal women aged 20 or older using the fifth Korea National Health and Nutrition Examination Survey (KNHANES V) data, which is representative of Korea.

\section{Materials and Methods}

\section{Study subjects}

KNHANES V data were collected for 3 years (2010 2012), using a rolling sampling survey that involved a complex, stratified, multistage, probability cluster survey of a representative sample of the non-institutionalized civilian population in South Korea. The survey was composed of three parts: a health interview survey, a health examination survey, and a nutrition survey. Each survey was conducted by specially trained interviewers. The interviewers were not provided with any prior information regarding specific participants before conducting the interviews. Participants provided written informed consent to participate in this survey, and we received the data in anonymized form. In the KNHANES $\mathrm{V}$ (2010 2012), 25,534 individuals over age 1 were sampled for the survey. Among them, we limited the analyses to adults aged $\geq 20$ years ( $n=19,392$ ). We excluded 2,138 subjects whose data were missing for important analytic variables, such as serum ferritin level or the mental health questionnaire. In addition, we excluded participants who had cancer (650 subjects) or hepatitis virus B (259 subjects) or hepatitis virus C (38 subjects) and the 211 subjects with suspected hemochromatosis (men, serum ferritin $>400 \mathrm{ng} / \mathrm{mL}$; women, serum ferritin $>300 \mathrm{ng} / \mathrm{mL}$ ) $[22,23]$. Finally, 16,096 subjects (6,840 men and 4,916 premenopausal and 4,340 postmenopausal women) were included in the statistical analysis. The KNHANES V (2010 2012) study has been conducted according to the principles expressed in the Declaration of Helsinki. (Institutional Review Board No, 2010-02CON-21-C; 2011-02CON-06-C; 2012-01EXP-01-2C). All participants in the survey signed an informed written consent form. Further information can be found in "The KNHANES V (2010 2012) Sample”, which is available on the KNHANES website [24]. The data from KNHANES is available on request by email if the applicant logs onto the "Korea National Health and Nutrition Examination Survey" website.

\section{General characteristics and blood chemistry}

Research subjects were classified by gender and by age into 20 29 years, 30 39 years, 40 49 years, 50 59 years, 60 69 years, and 70 years or older. The health categories of the participants were classified into three parts: drinking, smoking, and exercising. In the drinking category, the drinking II group included those who drank more than a glass of liquor per week, and drinking I group less than a glass of liquor per week, and the non-drinking group less than a glass of liquor per year. In the smoking category, participants who smoked more than one cigarette a day, those who previously smoked but do not presently smoke, and those who never smoked 
were classified into the current-smoking group, ex-smoking group, and non-smoking group, respectively. In the exercising category, the exercising group was classified as participants who exercised on a regular basis regardless of indoor or outdoor exercise (for $30 \mathrm{~min}$ at a time and per day in the case of moderate exercise, such as swimming slowly, doubles tennis, volleyball, badminton, and table tennis). Anthropometric measurements included measurement of height, weight, body mass index (BMI), and waist measurement (WM) and final measurements of systolic blood pressure (SBP) and diastolic blood pressure (DBP). Blood chemistry included measurement of total cholesterol (TC), high density lipoprotein cholesterol (HDL-C), triglyceride (TG), and fasting blood glucose (FBG).

\section{Serum ferritin measurement}

Serum ferritin was measured with a immunoradiometric assay (IRMA-mat Ferritin, DiaSorin, Stillwater, USA) using a 1470 WIZARD gamma-Counter (PerkinElmer, Turku, Finland).

\section{MetS and MSS}

MetS was defined using the diagnostic criteria of the National Cholesterol Education Program (NCEP) based on common clinical measures including TG, HDL-C, blood pressure, FBG, and WM. TG over $150 \mathrm{mg} / \mathrm{dL}$ was set as the criterion for elevated TG. The criteria for reduced HDL-C were HDL-C of less than $40 \mathrm{mg} / \mathrm{dL}$ and $50 \mathrm{mg} / \mathrm{dL}$ for men and women, respectively. FBG over $100 \mathrm{mg} / \mathrm{dL}$ was set as the criterion for elevated FBG. SBP over $130 \mathrm{mmHg}$ or DBP over $85 \mathrm{mmHg}$ or medication were set as the criteria for elevated blood pressure. The criteria for abdominal obesity were waist measurements of over $90 \mathrm{~cm}$ and $80 \mathrm{~cm}$ for men and women, respectively, according to the Asia-Pacific criteria [25]. The presence of defined abnormalities in any three of these five measures indicated a diagnosis of MetS. The metabolic syndrome score (MSS) indicates the presence of abdominal obesity, elevated blood pressure, elevated FBG, elevated TG, or reduced HDL-C. Subjects without any of the five risk factors received an MSS 0, and those with one, two, three, and more than four of the risk factors received an MSS score of 1 , 2,3 , and $\geq 4$, respectively [26].

\section{Data analysis}

The collected data were statistically analyzed using SPSS WIN version 18.0 (SPSS, Chicago, USA). The distributions of the participant characteristics were converted into percentages, and the successive data were presented as mean value with standard deviations. The mean value difference in serum ferritin levels for characteristics of the subjects and the MetS components were calculated using an independent t-test and analysis of variance (ANOVA). After modification of the serum ferritin level variable, the mean value difference in serum ferritin levels for MetS and MSS were calculated using an analysis of covariance (ANCOVA). The significance level for all of the statistical data was set as $p<0.05$.

\section{Results}

\section{General characteristics of research subjects}

General characteristics of the research subjects are shown in Table 1. According to the classification of risk factors for coronary artery disease and the MSS guidelines, 4,570 (28.4\%), 4,102 (25.5\%), 3,446 (21.4\%), 2,395 (14.9\%), and 1,583 (9.8\%) subjects were classified as MSS 0, MSS 1, MSS 2, MSS 3, and MSS $\geq 4$, respectively. The prevalence rate of MetS was 3,978 (24.7\%) of the 16,096 patients (men, 24.6\%; premenopausal women, $11.1 \%$; postmenopausal women, $40.3 \%$ ). The mean value of serum ferritin levels was $77.40 \pm 65.50 \mathrm{ng} / \mathrm{mL}$ (men, $115.89 \pm 72.12 \mathrm{ng} / \mathrm{mL}$; premenopausal women, $32.50 \pm 29.53 \mathrm{ng} / \mathrm{mL}$; postmenopausal women, $67.57 \pm 44.86 \mathrm{ng} / \mathrm{mL})$.

\section{Serum ferritin levels by subject characteristics}

Serum ferritin levels by subject characteristics were shown in Table 2. In the men group, serum ferritin levels were associated with age $(p<0.001), \operatorname{BMI}(p<0.001), \operatorname{TC}(p<0.001)$, alcohol behavior $(p<0.001)$, and smoking status $(p<0.001)$. In the premenopausal women group, serum ferritin levels were associated with age $(p<0.001)$, BMI $(p<0.001)$, TC ( $p=0.029$ ), and smoking status ( $p=0.002$ ). In the postmenopausal women group, serum ferritin levels were associated with age $(p<0.001)$, BMI $(p<0.001)$, and alcohol behavior $(p=0.032)$. 
Table 1. General characteristics

\begin{tabular}{|c|c|c|c|c|c|}
\hline \multirow[b]{2}{*}{ Variables } & \multirow[b]{2}{*}{ Category } & \multirow{2}{*}{$\begin{array}{c}\text { Total } \\
(n=16,096)\end{array}$} & \multirow{2}{*}{$\begin{array}{c}\text { Men } \\
(n=6,840)\end{array}$} & \multicolumn{2}{|c|}{ Women $\quad(n=9,256)$} \\
\hline & & & & $\begin{array}{l}\text { Premenopausal } \\
\quad(n=4,916)\end{array}$ & $\begin{array}{l}\text { Postmenopausal } \\
\quad(n=4,340)\end{array}$ \\
\hline \multirow[t]{6}{*}{ Age (years) } & $20 \sim 29$ & $1,821(11.3)$ & 739 (10.8) & $1,082(22.0)$ & None \\
\hline & $30 \sim 39$ & $3,141(19.5)$ & $1,300(19.0)$ & $1,835(37.3)$ & $6(0.2)$ \\
\hline & $40 \sim 49$ & $2,983(18.5)$ & $1,310(19.2)$ & $1,512(30.8)$ & $161(3.7)$ \\
\hline & $50 \sim 59$ & $3,116(19.4)$ & $1,300(19.0)$ & 487 (9.9) & $1,473(33.9)$ \\
\hline & $60 \sim 69$ & $2,680(16.7)$ & $1,207(17.6)$ & None & $1,428(32.9)$ \\
\hline & $\geq 70$ & $2,355(14.6)$ & $984(14.4)$ & None & $1,272(29.3)$ \\
\hline \multirow{3}{*}{ Smoking status } & Non-smoker & $9,699(60.3)$ & $1,417(20.7)$ & $4,251(86.5)$ & 4,031 (92.9) \\
\hline & Ex-smoker & $3,141(19.5)$ & 2,659 (38.9) & $344(7.0)$ & $138(3.2)$ \\
\hline & Current smoker & $3,256(20.2)$ & $2,764(40.4)$ & $321(6.5)$ & $171(3.9)$ \\
\hline \multirow[t]{3}{*}{ Alcohol behavior } & No Drinking & $4,758(29.6)$ & $1,231(18.0)$ & $1,298(26.4)$ & $2,229(51.4)$ \\
\hline & Drinking< once a week & $3,026(18.8)$ & $694(10.1)$ & $1,345(27.4)$ & $987(22.7)$ \\
\hline & Drinking $\geq$ once a week & $8,312(51.6)$ & 4,915 (71.9) & $2,273(46.2)$ & $1,124(25.9)$ \\
\hline \multirow[t]{2}{*}{ Physical activity } & No exercising & $11,696(72.7)$ & $6,204(90.7)$ & $4,552(92.6)$ & $3,942(90.8)$ \\
\hline & Current exercising & 4,400 (27.3) & $636(9.3)$ & $364(7.4)$ & $398(9.2)$ \\
\hline \multirow[t]{5}{*}{ MSS } & 0 & $4,570(28.4)$ & $1,730(25.3)$ & $2,301(46.8)$ & $539(12.4)$ \\
\hline & 1 & $4,102(25.5)$ & $1,791(26.2)$ & $1,364(27.7)$ & $947(21.8)$ \\
\hline & 2 & $3,446(21.4)$ & 1,637 (23.9) & $703(14.3)$ & $1,106(25.5)$ \\
\hline & 3 & $2,395(14.9)$ & $1,100(16.1)$ & $354(7.2)$ & $941(21.7)$ \\
\hline & $\geq 4$ & $1,583(9.8)$ & $582(8.5)$ & 194 (3.9) & 807 (18.6) \\
\hline \multirow[t]{2}{*}{ MetS } & MSS $<3$ & $12,118(75.3)$ & $5,158(75.4)$ & $4,368(88.9)$ & $2,592(59.7)$ \\
\hline & $M S S \geq 3$ & $3,978(24.7)$ & $1,682(24.6)$ & $548(11.1)$ & $1,748(40.3)$ \\
\hline BMI $\left(\mathrm{kg} / \mathrm{m}^{2}\right)$ & & $23.67 \pm 3.37$ & $24.02 \pm 3.13$ & $22.62 \pm 3.53$ & $24.29 \pm 3.28$ \\
\hline WM (cm) & & $81.13 \pm 9.95$ & $84.58 \pm 8.87$ & $75.37 \pm 9.42$ & $82.21 \pm 9.22$ \\
\hline $\mathrm{SBP}(\mathrm{mmHg})$ & & $119.81 \pm 17.31$ & $122.43 \pm 15.88$ & $109.61 \pm 13.76$ & $127.22 \pm 17.89$ \\
\hline $\mathrm{DBP}(\mathrm{mmHg})$ & & $76.28 \pm 10.48$ & $79.16 \pm 10.57$ & $72.12 \pm 9.40$ & $76.47 \pm 9.94$ \\
\hline $\mathrm{TC}(\mathrm{mg} / \mathrm{dL})$ & & $189.89 \pm 36.42$ & $188.15 \pm 35.67$ & $181.95 \pm 33.57$ & $201.61 \pm 37.73$ \\
\hline TG (mg/dL) & & $130.76 \pm 101.71$ & $152.18 \pm 121.56$ & $96.56 \pm 71.62$ & $135.73 \pm 84.84$ \\
\hline $\mathrm{HDL}-\mathrm{C}(\mathrm{mg} / \mathrm{dL})$ & & $52.63 \pm 12.81$ & $49.30 \pm 11.98$ & $57.35 \pm 12.82$ & $52.53 \pm 12.38$ \\
\hline $\mathrm{FBG}(\mathrm{mg} / \mathrm{dL})$ & & $97.78 \pm 22.19$ & $100.58 \pm 24.30$ & $91.35 \pm 16.48$ & $100.64 \pm 22.83$ \\
\hline Ferritin (ng/mL) & & $77.40 \pm 65.50$ & $115.89 \pm 72.12$ & $32.50 \pm 29.53$ & $67.57 \pm 44.86$ \\
\hline
\end{tabular}

n (\%), M \pm SD.

Abbreviation: MSS, metabolic syndrome score; MetS, metabolic syndrome; BMI, body mass index; WM, waist measurement; SBP, systolic blood pressure; DBP, diastolic blood pressure; TC, total cholesterol; TG, triglyceride; HDL-C, high density lipoprotein cholesterol; FBG, fasting blood glucose.

\section{Serum ferritin levels by MetS and MSS}

Means comparisons of serum ferritin levels by MetS and MSS are shown in Table 3 and 4. In men and premenopausal women groups, serum ferritin levels were associated with all components of the MetS. However, in the postmenopausal women group, serum ferritin levels were not associated with elevated blood pressure $(p=0.397)$. After modification of associate variable of serum ferritin levels, its mean value $(\mathrm{M} \pm \mathrm{SE})$ was significantly higher $(p<0.001)$ in the MetS group (men, $132.25 \pm 1.98 \mathrm{ng} / \mathrm{mL}$; premenopausal women, $39.89 \pm 1.49 \mathrm{ng} / \mathrm{mL}$; postmenopausal women, $73.45 \pm 1.14$ $\mathrm{ng} / \mathrm{mL}$ ) than the non- MetS group (men, $111.08 \pm 1.01 \mathrm{ng} / \mathrm{mL}$; premenopausal women, $32.26 \pm 0.50 \mathrm{ng} / \mathrm{mL}$; postmenopausal women, $63.26 \pm 0.98 \mathrm{ng} / \mathrm{mL})$. In addition, serum ferritin levels increased as MSS increased in all three gender-based groups $(p<0.001)$.

\section{Discussion}

The present study investigated the association between serum ferritin levels and MetS and MSS using data from KNHANES V, conducted in 2010 to 2012. When adjusted for variables associated with serum ferritin levels, the MetS and MSS were significantly associated with an increasing of serum ferritin levels in all gender-based groups (men, premenopausal 
Table 2. Serum ferritin levels according to general characteristics

\begin{tabular}{|c|c|c|c|c|c|c|c|}
\hline \multirow{3}{*}{ Variables } & \multirow{3}{*}{ Category } & \multirow{2}{*}{\multicolumn{2}{|c|}{ Men $(n=6,840)$}} & \multicolumn{4}{|c|}{ Women $(n=9,256)$} \\
\hline & & & & \multicolumn{2}{|c|}{ Premenopausal $(n=4,916)$} & \multicolumn{2}{|c|}{ Postmenopausal $(n=4,340)$} \\
\hline & & Ferritin (ng/mL) & $p$-value & Ferritin $(\mathrm{ng} / \mathrm{mL})$ & $p$-value & Ferritin $(\mathrm{ng} / \mathrm{mL})$ & $p$-value \\
\hline \multirow[t]{6}{*}{ Age (years) } & $20 \sim 29$ & $112.82 \pm 64.80$ & $<0.001$ & $33.02 \pm 25.68$ & $<0.001$ & None & $<0.001$ \\
\hline & $30 \sim 39$ & $128.30 \pm 71.96$ & & $31.26 \pm 29.02$ & & $74.49 \pm 41.43$ & \\
\hline & $40 \sim 49$ & $121.66 \pm 70.58$ & & $29.73 \pm 28.40$ & & $69.39 \pm 44.29$ & \\
\hline & $50 \sim 59$ & $114.71 \pm 72.25$ & & $36.24 \pm 29.45$ & & $64.82 \pm 42.76$ & \\
\hline & $60 \sim 69$ & $109.13 \pm 72.91$ & & None & & $66.40 \pm 42.58$ & \\
\hline & $\geq 70$ & $104.00 \pm 75.37$ & & None & & $71.81 \pm 49.35$ & \\
\hline \multirow[t]{2}{*}{ BMI $\left(\mathrm{kg} / \mathrm{m}^{2}\right)$} & $<25$ & $109.60 \pm 69.07$ & $<0.001$ & $31.33 \pm 28.22$ & $<0.001$ & $65.56 \pm 43.90$ & $<0.001$ \\
\hline & $\geq 25$ & $127.52 \pm 76.11$ & & $36.85 \pm 33.59$ & & $70.98 \pm 46.31$ & \\
\hline \multirow[t]{2}{*}{$\mathrm{TC}(\mathrm{mg} / \mathrm{dL})$} & $<200$ & $111.94 \pm 70.84$ & $<0.001$ & $31.89 \pm 27.67$ & 0.029 & $67.39 \pm 45.61$ & 0.789 \\
\hline & $\geq 200$ & $123.17 \pm 73.87$ & & $34.15 \pm 33.94$ & & $67.75 \pm 44.14$ & \\
\hline \multirow[t]{3}{*}{ Smoking status } & Non-smoker & $110.25 \pm 67.82$ & $<0.001$ & $31.93 \pm 29.62$ & 0.002 & $67.30 \pm 44.26$ & 0.355 \\
\hline & Ex- smoker & $113.85 \pm 73.85$ & & $35.44 \pm 30.65$ & & $70.83 \pm 47.65$ & \\
\hline & Current smoker & $120.75 \pm 72.28$ & & $36.99 \pm 26.45$ & & $71.32 \pm 55.59$ & \\
\hline \multirow[t]{3}{*}{ Alcohol behavior } & No drinking & $96.70 \pm 66.35$ & $<0.001$ & $33.14 \pm 32.25$ & 0.053 & $66.28 \pm 45.25$ & 0.032 \\
\hline & Drinking< <nce a month & $106.99 \pm 64.99$ & & $30.74 \pm 27.87$ & & $67.11 \pm 44.20$ & \\
\hline & Drinking $\geq$ once a month & $121.96 \pm 73.49$ & & $33.19 \pm 28.81$ & & $70.54 \pm 44.59$ & \\
\hline \multirow[t]{2}{*}{ Physical activity } & No exercising & $116.86 \pm 72.62$ & 0.087 & $31.70 \pm 28.65$ & 0.589 & $67.75 \pm 45.26$ & 0.382 \\
\hline & Current exercising & $111.89 \pm 68.02$ & & $32.56 \pm 28.90$ & & $65.68 \pm 40.53$ & \\
\hline
\end{tabular}

$\mathrm{M} \pm \mathrm{SD}$.

Abbreviation: 'See Table 1'.

Table 3. Serum ferritin levels according to MetS components

\begin{tabular}{|c|c|c|c|c|c|c|c|}
\hline \multirow{3}{*}{ Variables } & \multirow{3}{*}{ Category } & \multirow{2}{*}{\multicolumn{2}{|c|}{ Men $(n=6,840)$}} & \multicolumn{4}{|c|}{ Women $(n=9,256)$} \\
\hline & & & & \multicolumn{2}{|c|}{$\begin{array}{l}\text { Premenopausal } \\
\qquad(\mathrm{n}=4,916)\end{array}$} & \multicolumn{2}{|c|}{$\begin{array}{l}\text { Postmenopausal } \\
\quad(n=4,340)\end{array}$} \\
\hline & & Ferritin $(\mathrm{ng} / \mathrm{mL})$ & $p$-value & Ferritin (ng/mL) & $p$-value & Ferritin (ng/mL) & $p$-value \\
\hline \multirow[t]{2}{*}{$\mathrm{BP}(\mathrm{mmHg})$} & Normal & $113.67 \pm 69.62$ & $<0.001$ & $31.89 \pm 28.18$ & 0.002 & $67.04 \pm 43.62$ & 0.397 \\
\hline & Elevated blood pressure & $119.16 \pm 75.53$ & & $36.80 \pm 37.31$ & & $68.20 \pm 46.32$ & \\
\hline \multirow[t]{2}{*}{ WM (cm) } & Normal & $111.27 \pm 69.15$ & $<0.001$ & $31.04 \pm 28.03$ & $<0.001$ & $64.20 \pm 43.62$ & $<0.001$ \\
\hline & Abdominal obesity & $129.04 \pm 78.49$ & & $36.36 \pm 32.86$ & & $69.88 \pm 45.56$ & \\
\hline \multirow[t]{2}{*}{ TG (mg/dL) } & Normal & $107.23 \pm 66.89$ & $<0.001$ & $31.87 \pm 28.68$ & 0.001 & $64.86 \pm 42.15$ & $<0.001$ \\
\hline & Elevated triglyceride & $130.86 \pm 78.12$ & & $36.66 \pm 34.33$ & & $73.23 \pm 49.58$ & \\
\hline \multirow[t]{2}{*}{$\mathrm{HDL}-\mathrm{C}(\mathrm{mg} / \mathrm{dL})$} & Normal & $113.86 \pm 70.99$ & $<0.001$ & $31.20 \pm 27.62$ & $<0.001$ & $64.00 \pm 42.15$ & $<0.001$ \\
\hline & Reduced HDL-C & $123.82 \pm 75.83$ & & $35.73 \pm 33.58$ & & $72.05 \pm 47.74$ & \\
\hline \multirow[t]{2}{*}{$\mathrm{FBG}(\mathrm{mg} / \mathrm{dL})$} & Normal & $110.17 \pm 67.59$ & $<0.001$ & $31.25 \pm 27.60$ & $<0.001$ & $63.81 \pm 42.04$ & $<0.001$ \\
\hline & Elevated FBG & $126.87 \pm 78.95$ & & $41.25 \pm 39.47$ & & $74.46 \pm 48.95$ & \\
\hline \multirow[t]{2}{*}{ MetS } & MSS $<3$ & $110.03 \pm 68.41$ & $<0.001$ & $31.33 \pm 27.86$ & $<0.001$ & $63.53 \pm 41.11$ & $<0.001$ \\
\hline & $M S S \geq 3$ & $133.86 \pm 79.83$ & & $41.88 \pm 39.24$ & & $73.56 \pm 49.32$ & \\
\hline \multirow[t]{5}{*}{ MSS } & 0 & $102.27 \pm 68.87$ & $<0.001$ & $30.24 \pm 26.10$ & $<0.001$ & $59.40 \pm 35.36$ & $<0.001$ \\
\hline & 1 & $108.39 \pm 66.95$ & & $30.85 \pm 26.99$ & & $62.76 \pm 41.73$ & \\
\hline & 2 & $120.03 \pm 75.93$ & & $35.81 \pm 34.01$ & & $66.21 \pm 42.99$ & \\
\hline & 3 & $131.45 \pm 77.92$ & & $41.34 \pm 39.12$ & & $69.89 \pm 49.16$ & \\
\hline & $\geq 4$ & $138.41 \pm 83.19$ & & $42.86 \pm 39.53$ & & $77.84 \pm 49.19$ & \\
\hline
\end{tabular}

$\mathrm{M} \pm \mathrm{SD}$.

Abbreviation: 'See Table 1'.

Normal is defined as WM $<90 \mathrm{~cm}$ in men or $<80 \mathrm{~cm}$ in women, Abdominal obesity is defined as WM $\geq 90 \mathrm{~cm}$ in men or $\geq 80 \mathrm{~cm}$ in women, Elevated triglyceride is defined as TG $\geq 150 \mathrm{mg} / \mathrm{dL}$, Normal is defined as $\mathrm{HDL}-\mathrm{C} \geq 40 \mathrm{mg} / \mathrm{dL}$ in men or $\geq 50 \mathrm{mg} / \mathrm{dL}$ in women, Reduced $\mathrm{HDL}-\mathrm{C}$ is defined as $\mathrm{HDL}-\mathrm{C}<40 \mathrm{mg} / \mathrm{dL}$ in men or $<50 \mathrm{mg} / \mathrm{dL}$ in women, Normal is defined as FBG $<100 \mathrm{mg} / \mathrm{dL}$, Elevated FBG is defined as $F B G \geq 100 \mathrm{mg} / \mathrm{dL}$, Normal is defined as $\mathrm{SBP}<130 \mathrm{mmHg}$ or DBP $<85 \mathrm{mmHg}$, Elevated blood pressure is defined as $\mathrm{SBP} \geq 130 \mathrm{mmHg}$ or $\mathrm{DBP} \geq 85 \mathrm{mmHg}$. 
Table 4. Comparisons of serum ferritin levels for MetS and MSS

\begin{tabular}{|c|c|c|c|c|c|c|}
\hline \multirow{3}{*}{ Variables } & \multirow{2}{*}{\multicolumn{2}{|c|}{ Men $(n=6,840)$}} & \multicolumn{4}{|c|}{ Women $(n=9,256)$} \\
\hline & & & \multicolumn{2}{|c|}{ Premenopausal $(n=4,916)$} & \multicolumn{2}{|c|}{ Postmenopausal $(n=4,340)$} \\
\hline & Ferritin $(\mathrm{ng} / \mathrm{mL})^{\star}$ & $p$-value & Ferritin $(\mathrm{ng} / \mathrm{mL})^{\star \star}$ & $p$-value & Ferritin $(\mathrm{ng} / \mathrm{mL})^{\star \star \star}$ & $p$-value \\
\hline MSS 0 & $\begin{array}{c}103.05 \pm 1.86 \\
(99.40 \sim 109.70)\end{array}$ & $<0.001$ & $\begin{array}{c}30.72 \pm 0.79 \\
(29.16 \sim 32.27)\end{array}$ & $<0.001$ & $\begin{array}{c}60.61 \pm 2.05 \\
(56.59 \sim 64.64)\end{array}$ & $<0.001$ \\
\hline 1 & $\begin{array}{c}109.93 \pm 1.68 \\
(106.64 \sim 113.21)\end{array}$ & & $\begin{array}{c}31.11 \pm 0.69 \\
(29.77 \sim 32.45)\end{array}$ & & $\begin{array}{c}63.13 \pm 1.48 \\
(60.23 \sim 66.04)\end{array}$ & \\
\hline 2 & $\begin{array}{c}120.25 \pm 1.75 \\
(116.81 \sim 123.69)\end{array}$ & & $\begin{array}{c}34.95 \pm 1.18 \\
(32.63 \sim 37.27)\end{array}$ & & $\begin{array}{c}66.03 \pm 1.34 \\
(63.41 \sim 68.66)\end{array}$ & \\
\hline 3 & $\begin{array}{c}129.60 \pm 2.21 \\
(125.27 \sim 133.93)\end{array}$ & & $\begin{array}{c}39.80 \pm 1.68 \\
(36.50 \sim 43.10)\end{array}$ & & $\begin{array}{c}69.52 \pm 1.48 \\
(66.62 \sim 72.42)\end{array}$ & \\
\hline$\geq 4$ & $\begin{array}{c}134.90 \pm 3.09 \\
(128.84 \sim 140.95)\end{array}$ & & $\begin{array}{c}39.98 \pm 2.25 \\
(35.58 \sim 44.39)\end{array}$ & & $\begin{array}{c}77.37 \pm 1.64 \\
(74.15 \sim 80.60)\end{array}$ & \\
\hline Non-MetS & $\begin{array}{c}111.08 \pm 1.01 \\
(109.10 \sim 113.05)\end{array}$ & $<0.001$ & $\begin{array}{c}32.26 \pm 0.50 \\
(31.28 \sim 33.24)\end{array}$ & $<0.001$ & $\begin{array}{c}63.26 \pm 0.98 \\
(61.34 \sim 65.18)\end{array}$ & $<0.001$ \\
\hline MetS & $\begin{array}{c}132.25 \pm 1.98 \\
(128.36 \sim 136.14)\end{array}$ & & $\begin{array}{c}39.89 \pm 1.49 \\
(36.97 \sim 42.82)\end{array}$ & & $\begin{array}{c}73.45 \pm 1.14 \\
(71.22 \sim 75.68)\end{array}$ & \\
\hline
\end{tabular}

$\mathrm{M} \pm \mathrm{SE}$.

Abbreviation: 'See Table 1'.

*adjusted for age, BMI, TC, alcohol behavior, and smoking status **adjusted for age, BMI, TC, and smoking status **adjusted for age, $\mathrm{BMI}$, and alcohol behavior.

women, and postmenopausal women) (Table 4).

Serum ferritin is used as a clinical biomarker to evaluate iron status, and elevated serum ferritin concentration has been reported to be associated with the risk factors of cardiovascular disease such as diabetes mellitus, insulin resistance, and hypertension [6-9]. Each component of MetS is a risk factor for coronary artery disease, and MetS in which the components occur in a cluster with resistance to insulin is a useful indicator to identify groups at a high risk for cardiovascular disease [27,28].

Among previous studies on serum ferritin concentration and MetS, Li and colleagues reported that serum ferritin levels were positively associated with MetS in both Chinese men and women [29]. Moreover, Vari and colleagues reported that serum ferritin levels were positively associated with MetS in French men and premenopausal women and postmenopausal women [14]. On the other hand, in a study with US adults, Jehn and colleagues reported that serum ferritin levels were positively associated with MetS in premenopausal women and postmenopausal women, but not in men [20]. Moreover, in a study on Korean adults, Jeong and colleagues reported that serum ferritin levels were positively associated with MetS in men, but not in women [30]. In addition, Ryu and colleagues reported that serum ferritin levels were not associated with MetS in both men and women [18]. It is believed that the inconsistencies in previous domestic and foreign studies on serum ferritin concentration and MetS is due to the fact that serum ferritin levels vary across countries and races, and that previous studies targeted specific age groups and populations, such as adolescents, the aged, sexuality, the obese, and diabetes. The present study used the data of the entire adult population aged 20 and older from the KNHANES V data (2010 2012), which is representative of the Korean population. The results of our study showed that serum ferritin level of the MetS group was higher than that of the non-MetS group $(p<0.001)$ in the each of the gender-based groups. These results are consistent with previous studies $[14,29]$ that did find significant differences in serum ferritin related to MetS.

In addition to metabolic syndrome defined by NCEP-ATP III standards, the present study examined serum ferritin levels for increases in MetS components. Research on the association between serum ferritin levels and the increase of MetS components is rare. In a cross-sectional study among Italians, Bozzini and colleagues reported that the mean ferritin level was higher in the MetS group than in the non-MetS group and increased linearly with the increasing number of MetS components in Italian adults (mean values of $60.7 \mathrm{ng} / \mathrm{mL}$, 
$105.3 \mathrm{ng} / \mathrm{mL}$, and $142.3 \mathrm{ng} / \mathrm{mL}$ for none, one to three, and more than three MetS components, respectively, $p<0.001$ ) [31]. Avila and colleagues investigated the association between hyperferritinemia and iron consumption in Chileans, finding that the mean value of serum ferritin increases significantly with the number of risk factors related to MetS ( $p=0.043$ ) [32]. In addition, Jehn and colleagues investigated the association between serum ferritin and risk of the MetS in U.S. adults, and the trend of increasing mean ferritin values across categories of MetS components was significant for all three groups $(p<0.05)$ [20]. In the present study results, all of the variables, such as abdominal obesity, reduced HDL-C, elevated TG, elevated FBG, and elevated blood pressure, showed a significant difference in serum ferritin levels in both men and premenopausal women, but the elevated blood pressure showed no significant difference in postmenopausal women. Nevertheless, serum ferritin levels significantly increased with the increase in MetS components among the all of the gender-based group $(p<0.001)$.

Iron is an essential trace element for the human body, involved in cellular processes and a key component of various enzymes and is a transition metal capable of causing oxidative tissue damage by catalyzing the formation of free radicals [33]. Wilson and his colleagues have suggested that iron deposition in pancreatic beta cells may also impair insulin secretion in more advanced states of iron overload [34]. In addition, in a study by Niederau and his colleagues, results of oral glucose tolerance tests in patients with hemochromatosis have suggested that hepatic iron overload results in impaired insulin extraction [35]. Therefore, increase of iron stores may contribute to insulin resistance through mechanisms related to both reduced extraction of insulin and impaired insulin secretion.

The association between serum ferritin concentration and individual components of MetS varies between countries and races. In the present study results, although individual metabolic syndrome components may not be associated with serum ferritin concentration according to sex, increases of its components were positively associated with the serum ferritin concentration. In conclusion, MetS was associated with an increase in serum ferritin levels in Korean adults among all of the gender-based groups (men, premenopausal women, and postmenopausal women). As one of the reason for these results, we speculate that serum ferritin levels are increased with the MetS components increasing.

This study has several limitations. First, serum ferritin is an acute-phase reactant and may be increased under inflammatory conditions. We could not adjust for CRP as an inflammatory marker because it was not checked KNHANES V. Second, the information for dietary intake, which may influence body iron stores, is not concluded. Third, we could not analyze comprehensively the association of serum ferritin and MetS, due to lack of other iron-related markers such as trans-ferritin and total iron-binding capacity as a marker of body iron status. Fourth, because this study was a cross-sectional study, the ability to establish a causal relationship between serum ferritin and the MetS and increase of its components was limited. Therefore, more accurate results might be obtained by performing a cohort study.

\section{요 약}

본 연구는 국가자료인 2010 2012년도 국민건강영양조사 자 료를 이용하여 제 2형 당뇨병을 가진 대한민국 20세 이상 성인 16,096명(남성, 6,840명; 폐경 전 여성, 4,916명; 폐경 후 여성, 4,340 명)을 대상으로 대사증후군(MetS) 및 대사증후군 위험요소 의 증가(MSS)와 혈청 Ferritin수준의 관련성을 평가하고자 실시하 였다. 대사증후군의 발생률은 16,096명 중 3,978명으로 $24.7 \%$ (남성, $24.6 \%$; 폐경 전 여성, $11.1 \%$; 폐경 후 여성, $40.3 \%$ )이었다. 본 연구의 주요결과는 첫째, 관련변수를 보정한 후의 결과에서, 혈 청 ferritin 수준은 비 대사증후군(남성, $111.08 \pm 1.01 \mathrm{ng} / \mathrm{mL}$; 폐 경 전 여성, $32.26 \pm 0.50 \mathrm{ng} / \mathrm{mL}$; 폐경 후 여성, $63.26 \pm 0.98$ $\mathrm{ng} / \mathrm{mL}$ )에 비하여 대사증후군(남성, $132.25 \pm 1.98 \mathrm{ng} / \mathrm{mL}$; 폐경 전 여성, $39.89 \pm 1.49 \mathrm{ng} / \mathrm{mL}$; 폐경 후 여성, $73.45 \pm 1.14 \mathrm{ng} / \mathrm{mL}$ ) 에서 유의하게 증가하였다 $(p<0.001)$. 둘째, 남성과 폐경 전 및 폐 경 후 여성 모두에서, 혈청 ferritin 수준은 대사증후군 위험요소의 증가함에 따라 증가하였다 $(p<0.001)$. 결론적으로, 대한민국 성인 에서 대사증후군 및 대사증후군 위험요소의 증가는 혈청 ferritin 수준을 증가시킨다. 
Acknowledgements: None

Funding: None

Conflict of interest: None

\section{References}

1. Heeney MM, Andrews NC. Iron homeostasis and inherited iron overload disorders: an overview. Hematol Oncol Clin North Am. 2004;18(6):1379-1403.

2. Crichton RR. Inorganic biochemistry of iron metabolism. 3rd ed. New York: Ellis Horwood; 1991. p.29-58.

3. Halliwell B, Gutteridge JM. Role of free radicals and catalytic metal ions in human disease: an overview. Methods Enzymol. 1990;186:1-85.

4. Cook JD, Flowers CH, Skikne BS. The quantitative assessment of body iron. Blood. 2003;101(9):3359-3364.

5. Halliwell B. Oxidative stress, nutrition and health. Experimental strategies for optimization of nutritional antioxidant intake in humans. Free Radic Res. 1996;25(1):57-74.

6. Jiang R, Manson JE, Meigs JB, Ma J, Rifai N, Hu FB. Body iron stores in relation to risk of type 2 diabetes in apparently healthy women. JAMA. 2004;291(6):711-717.

7. Jehn ML, Guallar E, Clark JM, Couper D, Duncan BB, Ballantyne $\mathrm{CM}$, et al. A prospective study of plasma ferritin level and incident diabetes: The atherosclerosis risk in communities (ARIC) study. Am J Epidemiol. 2007;165(9):1047-1054.

8. Piperno A, Trombini P, Gelosa M, Mauri V, Pecci V, Verqani A, et al. Increased serum ferritin is common in men with essential hypertension. J Hypertens. 2002;20(8):1513-1518.

9. Cho YS, Kang JH, Kim SA, Shim KW, Lee HS. Association of serum ferritin and abdominal obesity and insulin resistance. J Korean Soc Study Obes. 2005;14(2):76-81.

10. Reaven GM. Role of insulin resistance in human disease. Diabetes. 1988;37(12):1598-1607.

11. Isomaa B, Almgren P, Torsen B, Laht K, Nissen M, Taskinen MR, et al. Cardiovascular morbidity and mortality associated with the metabolic syndrome. Diabetes Care. 2001;24(4):683-689.

12. McNeill AM, Rosamond WD, Girman CK, Golden SH, Schmidt ML, East HE, et al. The metabolic syndrome and 11-year risk of incident cardiovascular disease in the atherosclerosis Risk in Communities Study. Diabetes Care. 2005;28(2):385-390.

13. Thomas Jr FW. Metabolic syndrome, peripheral vascular disease and coronary artery disease: A concise review. Int J Angiol. 2010;19(3):e96-99.

14. Vari IS, Balkau B, Kettaneh A, Andre P, Tichet J, Fumeron F, et al. Ferritin and transferring are associated with metabolic syndrome abnormalities and their change over time in a general population: Data from an Epidemiological Study on the Insulin Resistance Syndrome (DESIR). Diabetes Care. 2007;30(7):17951801.

15. Ferrannini E. Insulin resistance, iron and liver. Lancet. 2000; 355(9222):2181-2182.

16. Li J, Wang R, Luo D, Li S, Xiao C. Association between serum ferritin levels and risk of the metabolic syndrome in Chinese adults: a population study. PLoS One. 2013;8(9):e74168. doi: 10.1371/journal.pone.0074168.

17. Raghavendra BM, Bharath MS, Veeranna Gowda KM, Ahmed MF, Yashavanth HS. Study of serum ferritin as a component of metabolic syndrome. IJSR. 2014;3(12):2383-2385.

18. Ryu SY, Kim KS, Park J, Kang MG, Han MA. Serum ferritin and risk of the metabolic syndrome in Korean rural residents. J Prev Med Public Health. 2008;41(2):115-120.

19. Marjani A, Akbari FA, Eshghinia S. Association between trace elements and metabolic syndrome among type 2 diabetes mellitus patients in Gorgan. Asian J Pharm Clin Res. 2015;8(3): 358-362.

20. Jehn M, Clark JM, Guallar E. Serum ferritin and risk of the metabolic syndrome in US adults. Diabetes Care. 2004;27(10): 2422-2428.

21. Sheu WH, Chen YT, Lee WJ, Wang CW, Lin LY. A relationship between serum ferritin and insulin resistance syndrome is present in non-diabetic woman but non-diabetic men. Clin Endocrinol. 2003;58(3):380-385.

22. Mainous AG, Wells BJ, Everett CJ, Gill JM, King DE. Association of ferritin and lipids with C-reactive protein. Am J Cardiol. 2004;93(5):559-562.

23. Milman N, Byg KE, Ovesen L, Kirchhoff M, Jủrgensen KS. Iron status in Danish women 1984-1994: a cohort comparison of changes in iron stores and the prevalence of iron deficiency and iron overload. Eur J Haematolog. 2003;71(1):51-61.

24. Ministry of Health and Welfare, Korea centers for disease control and prevention. Korea health statistics 2010: Korea national health and nutrition examination survey (KNHANES V-1) [cited by 2016 November 10] available from: https://knhanes. cdc.go.kr/knhanes/index.do.

25. WHO. Western pacific region. International association for the study of obesity task force, the asia-pacific perspective: redefining obesity and its treatment. Sydney: Health communications Australia; 2000. p15-21.

26. Yoon H, Kim GS, Kim SG, Moon AE. The Relationship between metabolic syndrome and increase of metabolic syndrome score and serum vitamin D levels in Korean adults: 2012 Korean National Health and Nutrition Examination Survey. J Clin Biochem Nutr. 2015;57(1):82-87.

27. Meigs JB. Invited Commentary: Insulin resistance syndrome syndrome X multiple metabolic syndrome a syndrome at all factor analysis reveals patterns in the fabric of correlated metabolic risk factors. Am J Epidemiol. 2000;152(10):908-911.

28. Grundy SM. Metabolic syndrome: a multiplex cardiovascular risk factor. J Clin Endocrinol Metab. 2007;92(2):399-404.

29. Li J, Wang R, Luo D, Li S, Xiao C. Association between serum ferritin levels and risk of the metabolic syndrome in Chinese adults: A population study. PLoS One. 2013;8(9):e74168.

30. Jeong DW, Lee HW, Cho YH, Yi DW, Lee SY, Son SM, et al. Comparison of serum ferritin and vitamin $d$ in association with the severity of nonalcoholic fatty liver disease in Korean adults. Endocrinol Metab. 2014;29(4):479-488.

31. Bozzini C, Girelli D, Olivieri O, Martinelli N, Bassi A, De Matteis $\mathrm{G}$, et al. Prevalence of body iron excess in the metabolic syndrome. Diabetes Care. 2005;28(8):2061-2063.

32. Avila F, Echeverría G, Pérez D, Martinez C, Strobel P, Castillo O, et al. Serum ferritin is associated with metabolic syndrome and 
red meat consumption. Oxid Med Cell Longev. 2015;2015: e769739.

33. Wolff SP. Diabetes mellitus and free radicals: free radicals, transition metals and oxidative stress in the aetiology of diabetes mellitus and complications. Br Med Bull. 1993;49(3):642-652.

34. Wilson JG, Lindquist JH, Grambow SC, Crook ED, Maher JF.
Potential role of increased iron stores in diabetes. Am J Med Sci. 2003;325(6):332-339.

35. Niederau C, Berger M, Stremmel W, Starke A, Strohmeyer G, Ebert R, et al. Hyperinsulinaemia in non-cirrhotic haemochromatosis: impaired hepatic insulin degradation? Diabetologia. 1984;26(6):441-444. 